\title{
"A world we don't know": the spatial configuration of sensory practices and production of knowledge in and around Mexican seismic monitoring
}

\author{
Elizabeth Reddy ${ }^{1}$
}

Colorado School of Mines, USA

\begin{abstract}
A single technoscientific knowledge project can entail many different kinds of knowledge production. Here, I show how a Mexican technoscientific knowledge project about seismicity requires diverse sensory practices and the production of knowledge about many kinds of environmental and social conditions. I argue that Mexican territorial politics frame this knowledge. Further, I demonstrate that these politics become evident in the very ways that knowledge about Mexico is configured spatially, that is, in topological and topographic ways that technicians and engineers come to understand and relate to Mexican territory. After situating this argument within contemporary critical attention to the production of geographic knowledge, I address it ethnographically. First, I describe how Mexican seismic monitoring is undertaken from the headquarters of the Centro de Instrumentación y Registro Sísmico (CIRES). Then, I deal with the arrangements of power that structure seismic monitoring and social conditions in what CIRES engineers and technicians call "the field." As I relate the sensory work and knowledge production that field teams do when they leave CIRES headquarters, I show how the things that field teams can know are shaped by territorial politics, and consequently reflect them.
\end{abstract}

Key Words: Mexico, environmental monitoring, sense, knowledge, earthquakes

\section{Résumé}

Un projet de connaissances technoscientifiques peut impliquer de nombreux types de production de connaissances. Je montre ici comment un projet de connaissance technoscientifique mexicain, relatif à la sismicité, requiert diverses pratiques sensorielles et la production de connaissances sur de nombreux types de conditions environnementales et sociales. Je soutiens que les politiques territoriales mexicaines encadrent cette connaissance. En outre, je démontre que ces politiques se manifestent de la même manière que la connaissance du Mexique est configurée spatialement, c'est-à-dire de manière topologique et topographique que les techniciens et les ingénieurs en viennent à comprendre le territoire mexicain et à le comprendre. Après avoir placé cet argument au centre de l'attention critique contemporaine portée à la production de connaissances géographiques, je l'adresse de manière ethnographique. En premier lieu, je décris comment le contrôle sismique mexicain est effectué depuis le siège du Centro de Instrumentación y Registro Sísmico (CIRES). Ensuite, je traiterai des arrangements de pouvoir qui structurent la surveillance sismique et les conditions sociales dans ce que les ingénieurs et techniciens du CIRES appellent "le terrain." En relatant le travail sensoriel et la production de connaissances effectués par les équipes de terrain après leur départ du siège du CIRES, je montre comment les éléments que les équipes de terrain peuvent connaître sont façonnés par la politique territoriale et, par conséquent, les reflètent.

\footnotetext{
${ }^{1}$ Dr. Elizabeth Reddy, Teaching Assistant Professor, Engineering, Design and Society, Colorado School of Mines, 1500 Illinois St., Golden, CO, 80401, USA. Email: reddy "at" mines.edu. I am indebted to all the participants and supporters of this research, particularly the team at CIRES. I acknowledge funding support for this research from a National Science Foundation Doctoral Dissertation Research Improvement Grant in Anthropology (\#1357388), a Dissertation Research Grant from the University of California Institute for Mexico and the United States, a Melvin Kranzberg Fellowship from the Society for the History of Technology, a Grant-in-Aid from the American Institute of Physics, and a Graduate Fellowship from the Newkirk Center for Science and Society at the University of California-Irvine. This article includes material that was presented at the meetings of the American Association of Geographers, American Anthropological Association, and Society for Applied Anthropology meetings in 2015. I am grateful to the anonymous reviewers and to Stephen Campbell Rea, Charis Boke, Malte Ziewitz, Vincent Ialenti, Lara Houston, Roberto Barrios, Hayden Kantor, Ashley Smith, Anaar Desai-Stephens, Bill Maurer, and Valerie Olsen for comments on this paper or its earlier drafts. All errors and shortcomings remain my own.
} 
Mots-clés: Mexique, surveillance de l'environnement, sens, connaissances, tremblements de terre

\section{Resumen}

Un proyecto de conocimiento tecnocientífico puede implicar muchos tipos de producción de conocimiento. Aquí, muestro cómo un proyecto mexicano de conocimiento tecnocientífico sobre sismicidad requiere diversas prácticas sensoriales y producción de conocimiento sobre muchos tipos de condiciones ambientales y sociales. Yo discuto que este conocimiento esta enmarcada por la política territorial mexicana. Además, yo muestro que estas políticas se hacen evidentes en cómo los técnicos e ingenieros configuran conocimiento sobre México en maneras topológicas y topográficas. Después de yo ubico mi argumento en el contexto de atención crítica contemporánea sobre la producción de conocimiento geográfico, lo abordo etnográficamente. Primero, describo cómo se realiza el monitoreo sísmico en México desde la sede central del Centro de Instrumentación y Registro Sísmico (CIRES). Luego, yo trazo el arreglamiento del poder que estructura ambos el monitoreo sísmico y las condiciones sociales en lo que los técnicos y ingenieros de CIRES llaman "el campo." Cuándo yo relato el trabajo sensorial y la producción de conocimiento que hacen los equipos de campo cuando salen de la sede de CIRES, yo demuestro cómo las cosas que los equipos de campo pueden conocer están moldeadas por la política territorial y, en consecuencia, la reflejan.

Palabras clave: México, monitoreo ambiental, la sensación, conocimeinto, sísmos

\section{Introduction}

Throughout the headquarters of the Centro de Instrumentación y Registro Sísmico (CIRES), flat screens display a digital map of Mexico in deep green and sandy brown (Figure 1). Every so often, bright rings spread across it. These are the P- and S- waves of earthquakes, expanding smoothly out from their epicenters through Mexican territory. The rings spread past vibrant dots. Some of the dots represent the field stations set up to register earthquakes and others are the Mexican cities that benefit from warnings about earthquakes, but the map does not focus on them. This map is designed to show Mexican earthquakes as they are detected and presents them simply and coherently, extrapolating from what field stations register. It displays Mexico's earthquake early warning system at work. The broadcast alerts that the system triggers give some people enough warning before earthquakes reach them that they can evacuate or take shelter. Earthquake early warnings like Mexico's are increasingly popular around the world, and can help save property and even lives from quakes. ${ }^{2}$ Keeping the Sistema de Alerta Sísmica Mexicano running entails many kinds of sensory practice and knowledge production—and requires understanding Mexican territory in very different ways.

This earthquake early warning system can be understood as one of many state-supported efforts to know, and enact power in, Mexican territory (see Craib 2004; Mathews 2006). ${ }^{3}$ Critical cartographers consider such projects to be political undertakings (for example, Crampton 2003; Dodge, Kitchen, and Perkins 2011; and Harley 1989). In this article, I explore this system's politics with ethnographic attention to what geographer and social theorist Jess Bier has recently called the "geographic production of knowledge" (Bier 2017: 13). That is to say, I interrogate what Bier describes as the material, technical, and conceptual conditions involved in producing knowledge and geopolitical territory itself in context. The necessity of addressing how such conditions and contexts are made to relate-that is, in parsing how Mexican territorial politics inform the sensory practices and knowledge production necessary for seismic monitoring-became evident to me when my requests to observe work at the 98 seismic field stations of the earthquake early warning system were politely but firmly refused.

In interviews, formal presentations, and casual discussion in CIRES offices, field teams told stories that helped me understand why. They discussed the material, technical, conceptual conditions that coincide with the extension of their seismic monitoring system as well as the political contexts in which the Sistema Alerta Sísmica Mexicano has taken shape. They described long trips and close quarters; insects, animals, and plant-

\footnotetext{
${ }^{2}$ Strauss and Allen (2016) present an excellent panorama of how such technologies are currently used around the world.

${ }^{3}$ This is not to discount the significant and noteworthy efforts to bring other kinds of knowledge in to mapping practices; see Kitchin and Dodge (2007) and Verplanke et al. (2016) for discussions of these strategies.
} 
life; bad food and flooded roads and the pervasive social effects of organized crime. ${ }^{4}$ As they talked about the requirements of the technologies they use and maintain, they also reflected on Mexico itself and the territory that their work requires them to get to know in a variety of ways. Their stories about seismic monitoring demonstrated the consequences of Mexican territorial politics, particularly the effects of longstanding inequalities between remote rural places and wealthy and central Mexico City. Listening to their stories, I came to understand that what intrigued me about their routine field work also made CIRES engineers and technicians reluctant to take responsibility for my wellbeing in what they called "the field."

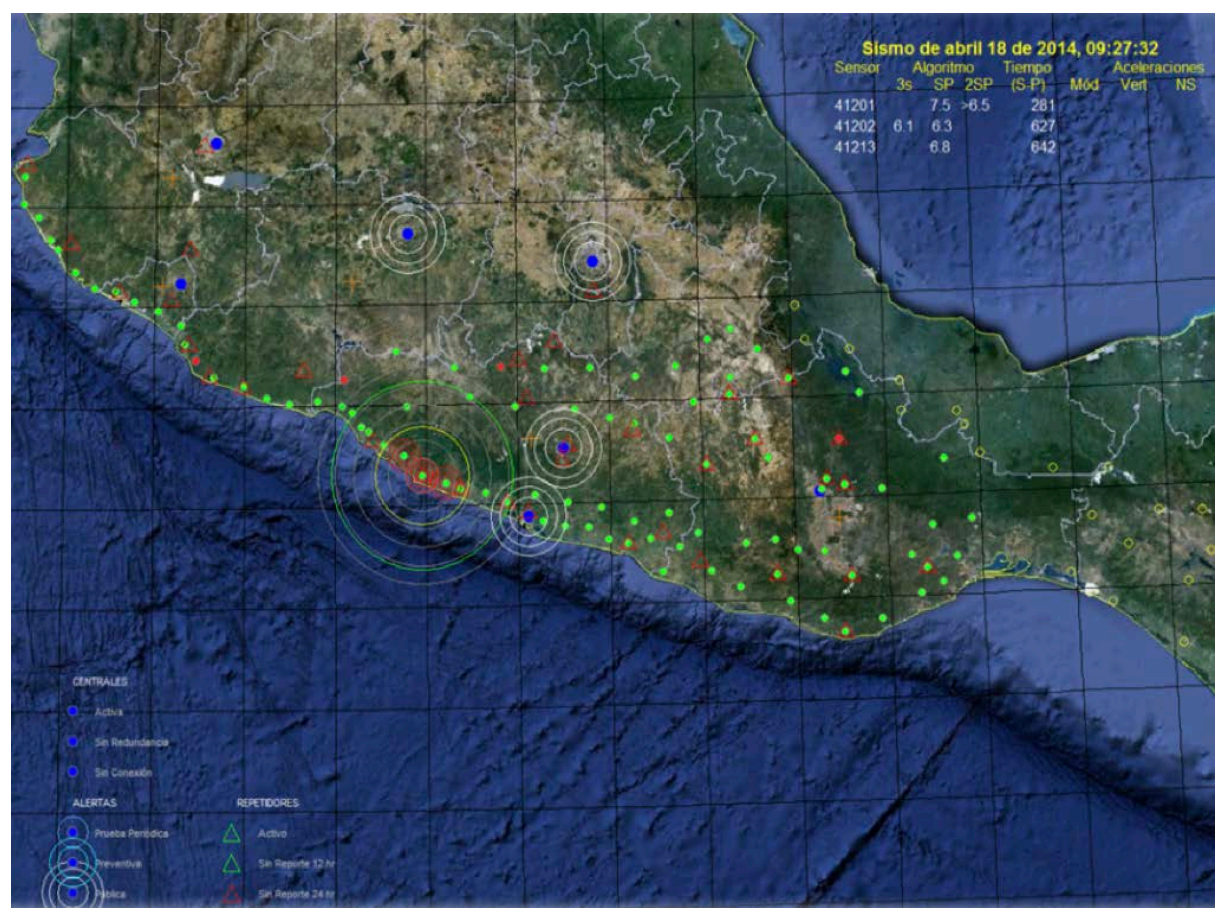

Figure 1: A map of the Sistema Alerta Sísmica Mexicano, showing the Good Friday earthquake of April 18, 2014. Source: CIRES 2014.

In this article, I draw on ethnographic research that I carried out while embedded at CIRES offices over 10 months during 2014. This research involved observation and participant observation in meetings, presentations, and every-day office work, as well as 22 formal interviews and survey research with engineers, technicians and administrative staff in senior, management, and non-management roles in the organization. ${ }^{5}$ Using these methods, I show how a Mexican technoscientific knowledge project about seismicity requires

\footnotetext{
${ }^{4}$ I use "organized crime" rather than "narcoviolence" here because of the diversity of dangerous and illegal projects that engineers and technicians might have encountered in rural Mexico in 2014. These are not necessarily directly drug-related. For example, self-defense leagues are also extremely dangerous (Asfura-Heim and Espach 2013). However, I acknowledge that it is difficult to refer to perpetrators of this violence as "criminals" when evidence suggests that their organizations carry out some of the roles and duties of a traditional government (Grayson 2010) even as they make heavy use of spectacular intimidation and brutality (see Lantz 2016). Further, observers of Mexico's drug war in and outside of academia have been increasingly critical of the state's role in this violence. As Alejandro Zagato points out, the Mexican activist slogan "it was the state!" should direct our attention to how violence is enacted and enabled not just by organizations that have taken on state functions, but also by the Mexican state itself (2018).

${ }^{5}$ Reporting with greater detail on the demographics of interviews might compromise anonymity. Spanish is the language used in this organization, and meetings, presentations, office work, conversations, formal interviews, surveys reported on here happened in that language. Translations are the author's.
} 
diverse sensory practices and the production of knowledge about many kinds of environmental and social conditions. I argue that Mexican territorial politics inform and emerge from this knowledge. Further, I demonstrate that these politics become evident in the very ways that knowledge about Mexico is configured spatially, that is, in the topological and topographic ways that technicians and engineers come to understand, and relate to, Mexican territory.

Political ecologists like Mara Goldman and Matthew Turner promote study of how "scientific understandings of the environment are packaged, stabilized, and circulated ....and with what effects" (2011: 9), so developing a robust conceptual toolkit for analyzing the relations between practices, knowledge, and politics is important. While I explore how the topology and topography of knowledge can reflect territorial politics, I engage with dynamic scholarly conversation about how exactly multiple ways of sensing and knowing environments exist in the scope activities or forms of knowledge that we might understand as technoscientific (see Forsyth 2003; Lave 2012).

Here, I engage with the Mexican earthquake early warning system as part of a "nature regime" of multiple and irreducible relations (Escobar 1999: 5; also see Biersack 2006) distinctive of technoscientific environmental monitoring work. ${ }^{6}$ This kind of monitoring is an increasingly common kind of knowledge project that involves networks of sensory tools, communications systems, automated analyses, and human designers, technicians and various users in the production of knowledge (Edwards 2010; Gabrys 2016; Nadim 2016). To address the sensory practices and knowledge production entailed in this particular monitoring project, I describe how Mexican seismic monitoring is undertaken from the headquarters of CIRES. Then, I turn to the arrangements of power that structure seismic monitoring and social conditions in what CIRES engineers and technicians call "the field." I analyze how Mexican territorial politics emerge in the diverse sensory work and knowledge production that field teams do when they leave CIRES headquarters. Inequities can become particularly obvious in exposure to hazards and their impacts (Collins 2008; Oliver-Smith 1996; Tierney 2007). ${ }^{7}$ As I explore seismic monitoring in Mexico, I demonstrate that this insight is relevant to knowledge about earthquakes as well as to earthquake effects.

\section{Sensing and producing knowledge}

The Sistema de Alerta Sísmica Mexicano has been in operation since the early 1990s, and it relies on a network of accelerometers distributed around the nation to automatically register and analyze seismic motion and then broadcast warnings about earthquakes to cities across Mexico (Espinosa Aranda et al. 2009, 2011). This technology has been developed explicitly around earthquakes. However, recent political ecology research on environmental knowledge production suggests that we avoid approaching technoscientific knowledge projects like this as singular. Instead, such undertakings be understood to contain multiple and divergent practices and outcomes (Eren 2017; Rocheleau 2011), and they frame new relations (Rahder 2014).

Diverse as they are, the sense practices and knowledge produced in relation to Mexican seismic monitoring are not easily separated. Ethnographer Kathryn Geurts has considered sense to be a matter of "order", that is, a "pattern of relative importance and differential elaboration... made possible and limited" (2002: 5), constituting an emerging, performative relation between a territory and the tools for mapping it. Indeed, anthropological research has shown that sense is enabled by material processes as well as interpretive frameworks, patterns, and cultures (Classen 1997; Geurts 2003; Howes 2003; Keating and Hadder 2010). Sense is not an individualized or removed affair, but it involves social collectives (Solomon 2010) and artifacts (Connor 2006; Henare et al. 2007); it is a matter of physically and conceptually situated encounter and coproduction (Csordas 1993; Hayward 2010; Seremetakis 1994). Sense, whatever its mode, is made possible and legible by social and conceptual processes. Sense may be produced by different organs or even by machine, but it emerges as meaningful in relation to what Geurts calls "order."

\footnotetext{
${ }^{6}$ I have addressed the public earthquake early warnings that the system generates elsewhere, see Reddy (2016).

${ }^{7}$ These same social conditions can also, sometimes, be related to violence. However, I follow Nancy Lee Peluso and Michael Watts' call to explore local, historically-situated processes that laminate environmental hazard, social inequity, and violence together rather than take the relations between these for granted (2001).
} 
Critical geographers and STS scholars draw attention to order when they consider how data or information are spatialized. ${ }^{8}$ Depending on how data are made and made to relate, they point out, knowledge about them can take different spatial forms. It can make different kinds of sense. For example, Celia Lury, Luciana Parisi, and Tiziana Terranova describe how attending to "discontinuities through repeated contrasts" yields topological knowledge (2012: 4; see also Martin and Secor 2014). Topological knowledge is one way to refer to baroque or maximally complex ways of rendering the world. It facilitates detailed attention to emergent relations and phenomena (see also Allen 2011; Elden 2013; Ruppert 2012; Steinberg and Peters 2015). Topological knowledge highlights distinctions and relations between here and there. John Allen argues that this "topological sensibility... prompts us to think again about such things as scale and territory" (2011: 284). He suggests that this is especially useful for addressing the relationship between politics and knowledge about territory.

This kind of order, or configuration, is essentially different from that which represents the consistent, static state-space that Raymond Craib, among others, has described. In Cartographic Mexico, Craib writes about how "both the Mexican state and the space it occupied were produced and rendered natural" in the nineteenth and early twentieth centuries (2004: 2). While Craib describes how profoundly ambivalent and complex the development of knowledge for Mexico's national territorial project could be, the production of fixed and codified spatial representations of the Mexican state are just as topographic as the simple digital map in CIRES headquarters. Both present knowledge about territory as consistent and total, without blind spots or irregularities. Topographic knowledge renders territory as fixed in ways that topological knowledge does not (see also Harvey 2012). For this reason, topography has often been understood as appropriate for rendering (and making claims about) state power in space. Topology, on the other hand, has been useful for describing tools that states can use to collect knowledge and enact their power in certain places based on emergent, differentiated, or inconsistently available information (see Allen 2011; Elden 2011; Martin and Secor 2013; Mezzadra and Nielson 2012; Paasi 2011).

Seismic monitoring entails knowledge production that is both topographic and topological. Sense made by accelerometers and the embodied practices of field workers contribute to the topographic digital map with which I opened this article. There, earthquake motion is mapped and rendered geometrically as continuous and consistent motion through Mexican territory. Seismic monitoring involves other configurations of knowledge too: emergent and changeable knowledge about equipment and conditions around field stations like El Herradero in the state of Michoacán. Field trips and seismic motion bring them into meaningful relation with those in places as varied as Zihuatanejo, Guerrero or Tututepec, Oaxaca.

This knowledge, however it is configured, is involved in what Stuart Elden calls "the process" of territory (2013: 36; see also Foucault 2009; Lefebvre 1994) — that is to say, it reflects and contributes to ongoing enactments of power in and through space. Mexico's seismic monitoring project has been developed in the context of severe inequalities that distinguish remote, rural places from wealthy and central Mexico City, and it is undertaken through not only these conditions but also the organized crime that has come to mark many places in rural Mexico. Experiences in the field, and knowledge produced through these, contribute to and are shaped by these conditions.

\section{Knowledge configurations at the center of coordination}

At CIRES's Mexico City headquarters, I watched more than a dozen engineers, technicians, administrators and advisors meet almost every week in fast-paced "Directors' Meetings" to address the organization's projects. CIRES leaders poured into the conference room around noon. The most senior of them would sit around a central table, the least senior back along the walls, where I sat to take notes. Most of the

\footnotetext{
${ }^{8}$ While critical geographers and STS scholars have developed these concepts as I use them here, they borrow heavily from mathematics to do so (Coleman 2011; Elden 2011; Lury et al. 2012; Marres 2012; and Paasi 2011). This treatment of spatialization owes a great deal to 18th and 19th century mathematics, particularly Euler's work (see Shields 2012 for a discussion). It is mostly the later non-Euclidean works that are cited as foundational mathematical topological theories (as described in Martin and Secor 2014).
} 
people around the table were men, but there were several women there too; there were fewer women in the organization than there were men, and, although there were several exceptions, most did not have leadership roles. As members of a technical elite, all these people were part of a community that has been incredibly influential in Mexican national policy decisions throughout the $19^{\text {th }}$ and $20^{\text {th }}$ century (see, for example, Bazant 2014; Ramos Lara and Rodríguez Benítez 2007). All had received specialized technical training. Many in the room held master's degrees and some even doctorates ${ }^{9}$; significant qualifications in a nation where only $51 \%$ of adults have graduated from secondary school and 22\% have any form of higher degree at all. ${ }^{10}$

The assembled representatives of CIRES's various departments would move briskly through their updates. The senior director tasked with running the meeting had been involved in the organization from the very beginning. He kept the conversation moving. He asked for an update on a co-worker's health before inviting a member of the non-profit's advisory board to discuss an interview with the press; requested that one department head to explain his newest tweaks to an algorithm in detail, then inquired about his team's ongoing effort to stimulate regulatory reform. He solicited information on the progress of efforts to take earthquake early warning live in a new city. He checked in about the conditions around a station in Michoacán, where violence had prevented CIRES from sending field teams for months. Each item was a topic for a few minutes only, with details provided by more junior members of the organization and then discussed by seniors and incorporated into short and long-term plans. Any issue related to the system, and keeping it up and running 24 hours a day, ready for unpredictable quakes, might be discussed.

Lucy Suchman has described places like CIRES headquarters as "centers of coordination" where experts enact what she calls an "orientation to problems of space and time" (1997: 42; see also Neyland 2006). Indeed, this was a powerful place from which to conceptualize Mexican territory. CIRES Directors met for strategic conversations about a seismic monitoring network developed in central and southern Mexico to produce warnings for handful of cities (that is, only Mexico City, Oaxaca City, Chilpancingo, Acapulco, Morelia, and Puebla) under the light of the digital map, pictured above, that extrapolated from this data to show seismicity's effects across the nation. This careful, particularistic treatment of the minutiae of earthquake monitoring at individual stations was a contrast to this sweeping map of Mexican earthquakes as well as the simplicity of the sirens that the system produced when it detected significant earthquakes. Indeed, the technical and embodied sensory practices that the Directors' Meetings directed and the knowledge to which their conversations referred was never just either generalized and national nor emergent and particularistic. With the support of the cities that they served - especially Mexico City, which is at once the nation's capital, a site of incredible wealth, and the most seismically sensitive city in the nation — it was both possible and essential for their seismic monitoring work to entail both topographic and topological knowledge.

On my way to Directors' Meetings, I could sometimes watch more junior engineers and technicians load up trucks and double check their equipment in a cramped parking lot within CIRES headquarters' cheerful yellow outer walls (Figure 2). For those who did fieldwork, it meant close collaboration even before leaving CIRES headquarters. Team leaders were younger men who had been with the organization long enough to take on such roles but not long enough to achieve wholly Mexico City-based positions. ${ }^{11}$ They would often try to make sure their teams left early in the morning, but some might still be preparing as midday approached. Field team members worked busily to prepare for these trips, running to a third floor office space, into storage in a spare office on the ground floor, and coming back weighed down with supplies. They knew more or less what equipment they would need for each station they planned to visit. Teams went to the field with detailed information about the particular condition of field stations, communicated by computers in the field stations themselves during twice-daily automatic check-ins or long-standing work plans devised at Directors' Meetings. Systems were set up so that they could easily contrast conditions at one place with those of another and make

\footnotetext{
${ }^{9}$ In an anonymous survey that I carried out in 2014 as part of my fieldwork at CIRES, 30 respondents, representing nearly half of the 74 engineers, technicians, and administrators who worked there at the time gave me context to understand seniority, educational attainment, and gender that I describe in this section. This is supported by observations and interviews.

${ }^{10}$ That is, adults between the ages of 25 and 64, as reported in SEP 2016.

${ }^{11}$ Interviews indicated that some of their female colleagues had gone to the field in the past, but while I visited it was not a mixed-gender undertaking.
} 
maintenance trips in light of topological knowledge about field stations. They knew, however, that what they would find at stations was bound to be surprising: that the field was a place of unpredictable challenges including but never limited to problems related to the earthquakes that the field stations were designed to register and analyze. Their trips to the field were framed by this preliminary topological knowledge.

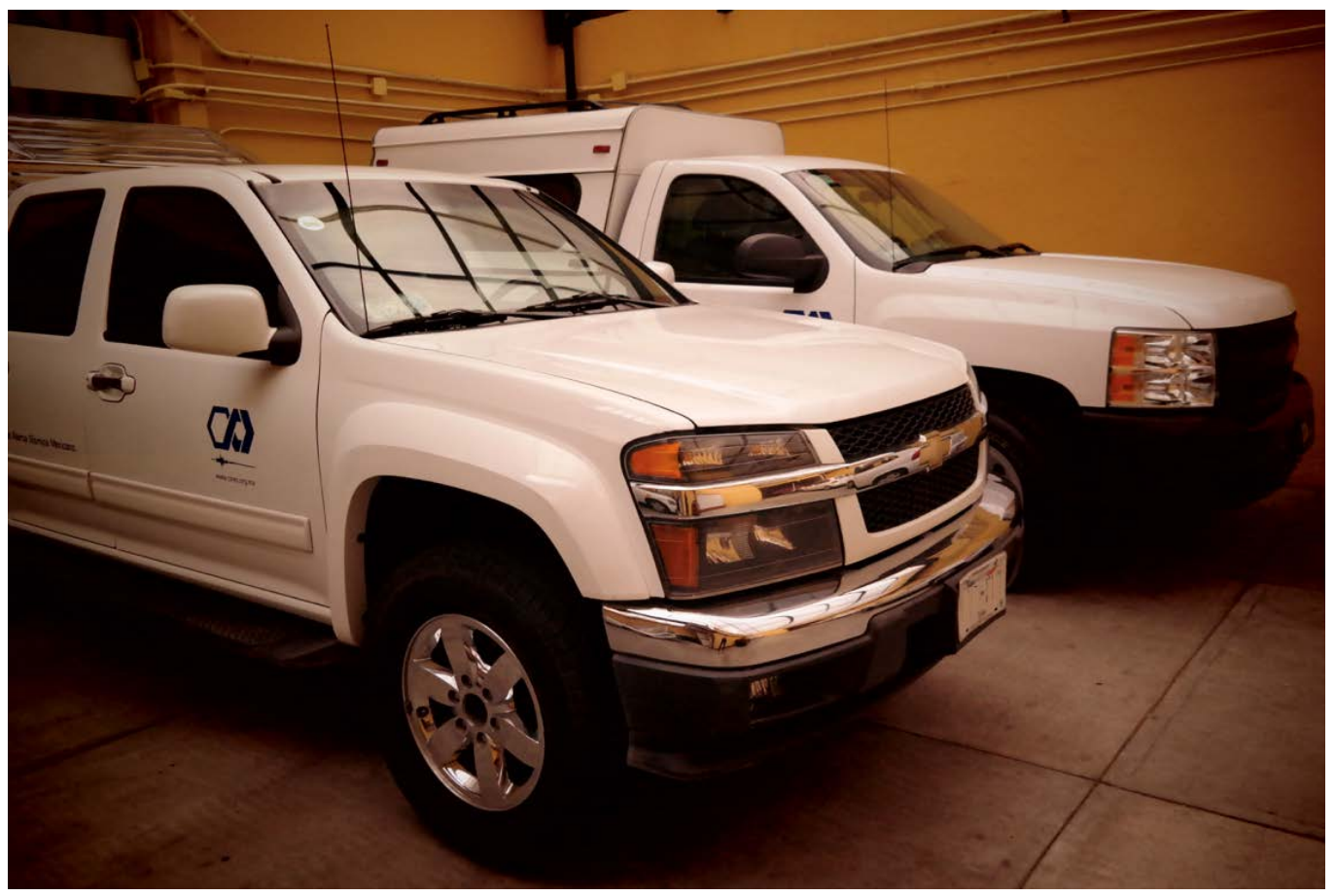

Figure 2: Trucks at CIRES headquarters, Mexico City. Source: Author, 2014.

Expecting to be surprised and to encounter conditions that exceeded the scope of what could be known from CIRES headquarters, these men would bring more than they had reason to believe they needed. They would not fix anything in the field - better to replace components wholesale and minimize system down-time. They organized great spools of cable in the beds of their white trucks beside large toolboxes full with anything that a field station might require. Trucks were also loaded with things necessary to gain access to the far-flung and remote stations: money for food, beds, and sometimes gifts or rent for local landowners. They brought keys to open the chain-fences that ring field stations to protect components from wildlife and thieves, big umbrellas to shade their work in sun and dripping rain, climbing gear for ascending radio towers to adjust cables or mounts on solar panels, and cameras to take photos of everything for later analysis and to illustrate their stories. Their paths to the field were necessarily framed by territorial politics.

\section{Into the field}

"It's really different when you go into the field," technician Rufio Gómez explained to me. He had been doing fieldwork related to CIRES's seismic monitoring network for a handful of years. He had traveled to stations around Mexico, and explained his experiences in the field as a matter of contrast. The field might contain any number of forces, agents, and conditions (Figure 3). It was, however, first and foremost a different kind of place than the busy room ringed with desks where Gómez and I sat in to discuss it, or, for that matter, from Mexico City itself, the wealthiest and most powerful place in the nation. "When you go out," he said, "it's another thing." 
Engineers and technicians described the territory they traveled through to make seismic monitoring possible using a language of broad distinction. Their organization's yellow-walled headquarters, a pair of converted residential buildings on a street roofed seasonally in purple jacaranda blooms in a middle-class neighborhood in Mexico City, was simply called "CIRES." The accelerometric stations they maintained and repaired were in "el campo", "the field." That distinction frames their encounters with the excessive, changeable environment. It also rearticulates sweeping modes of characterizing Mexico City and Mexican national territory. Their sensory practices, in other words, are built to some extent on a certain political topography of Mexican territory.

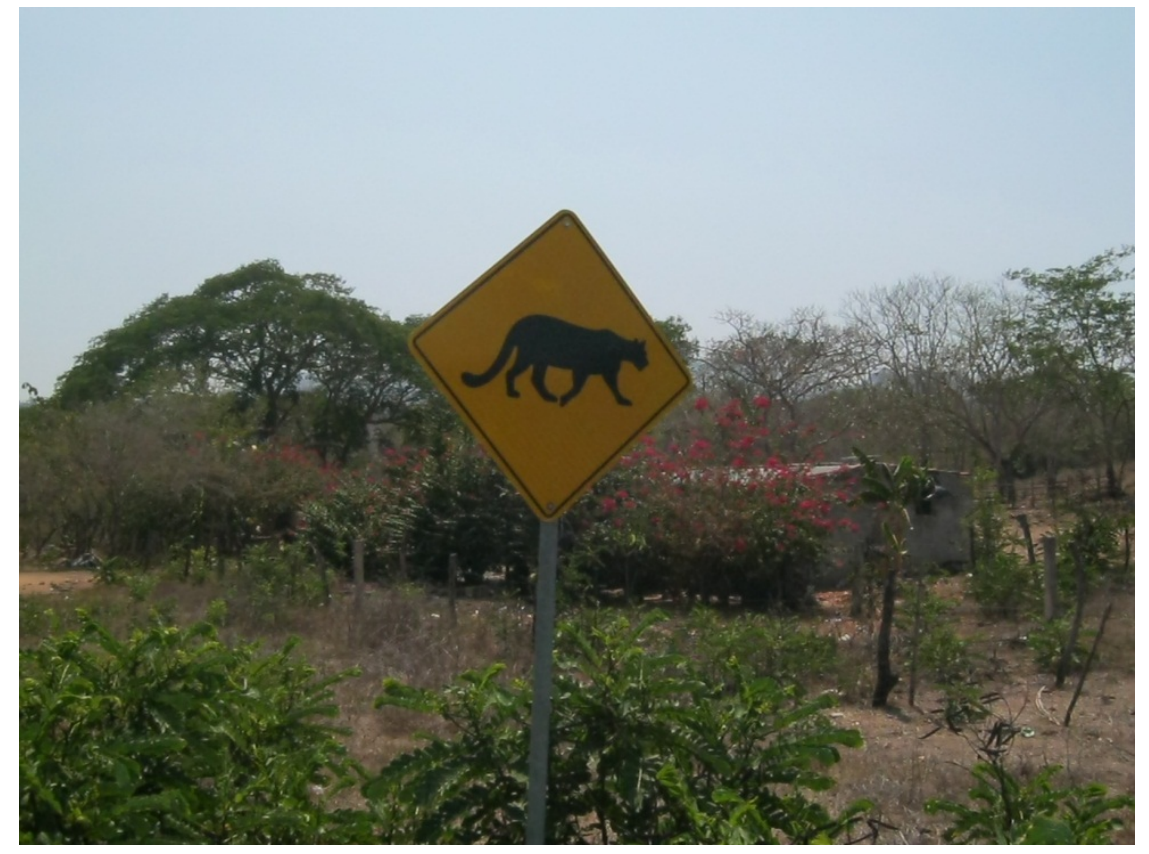

Figure 3: A sign that field teams were unlikely see in Mexico City. Source: CIRES 2014.

"The field" is a useful and troublesome construction familiar to many sciences (see Gupta and Ferguson 1997; Rival 2014). The field, for CIRES engineers and technicians, is a general category, but is used in relation to an assemblage of often-remote sites in the altiplano of western and central-southern Mexico, made relevant by the presence of seismic stations. For CIRES engineers and technicians, the field is the kind of place that one drives for hours and sleeps in strange beds for days at a time in order to reach. It is also an all-purpose name for the territory that they drive through in order to get there. Field stations are spread throughout six states, situated in different bioregions, subject to different air currents, and arranged to detect seismic energies released at different depths, but they comprise a single kind of place nonetheless.

This elision reveals a political geography that places Mexico City at the center of the nation when compared to what some people call "las provinces" or "the provinces." This term bears connotations of the periphery, and relative unimportance. ${ }^{12}$ Such distinction-making between rural and urban Mexico is meaningful. Indeed, some observers have considered the differences it marks to be so extreme that it became appropriate to discuss them as two civilizations (Bonfil Batalla 2004: xv). Although grounding this contrast in specific regional logics (Lomnitz-Adler 1991), peasant and popular movements (Guardino 2002; Joseph and Nugent 1994), and shifting agrarian policies and modes of production (Bartra 1993) offer more nuanced perspectives on the ways

\footnotetext{
${ }^{12}$ Conversations with historian of science Adriana Minor Garcia have been critical for helping me see how this language works to diminish places outside of Mexico City.
} 
these differences are structured, ${ }^{13}$ the radical distinctions that people make between rural and urban Mexico are important to note. ${ }^{14}$

Even though the field may be a single, general kind of place for CIRES technicians and engineers-a contiguous Other to their Mexico City home - their sensory practices frame more particularistic topological knowledge too. The seismic monitoring system's network of field stations (Figure 4) has expanded over the course of its three decades, and locations for field stations have been chosen, spread along active faults likely to produce seismicity dangerous to its handful of user communities (see Cuéllar et al. 2010; Espinosa-Aranda et al. 2009). ${ }^{15}$ Changeable conditions around these stations might constitute diverse immediate challenges to the project of producing a straightforward seismic map of Mexico and simple early warning before earthquakes strike.

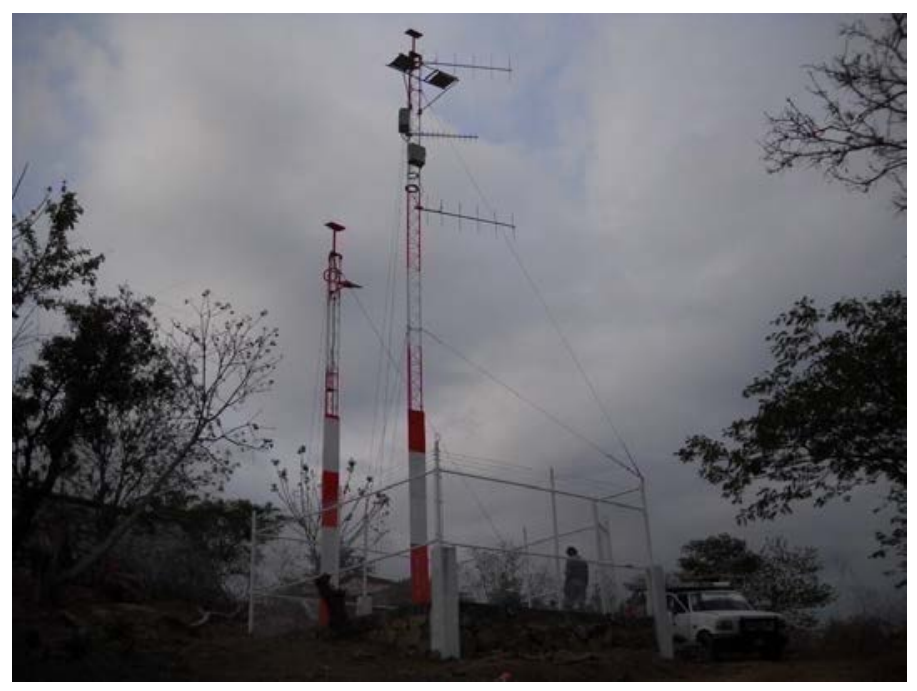

Figure 4: A field station. Source: CIRES, 2018.

Engineers and technicians narrate their "field" as a territory in which many environmental and social systems coincide, laminated together and productive of complex relationships through space. Their work at field stations means that engineers and technicians rapidly encounter some of these. Along the Pacific Coast, in the states of Guerrero and Michoacán, the air is high in humidity and salty from the ocean with material effects for those station components that can be corroded. The mountains form a sort of barricade between these tropical climates and places that can claim, at least, dry winters. Coastal storms blow in from the west every year in the summer and fall, and violent thunderstorms can pour water on field stations. Power surges from lightning could mean false alerts or completely disable a station. The storms constrained station maintenance and repair visits to the drier winter months. To the south, inland field stations don't suffer the same storms, although the weather in the mountains is much the same: tropical spaces out of which mountains rise to drier, higher ground. Stations there were subject to some of the same slow threats as those on the Pacific coast, though, as insects and animals chewed at wire casings, hives of bees or wasps took up residence on solar panels, and moisture fouled electronics. Humans could trouble seismic sensing just as surely as any other kind of damage could. They could

\footnotetext{
${ }^{13}$ As Cynthia Hewitt de Alcántara's history of research in rural Mexico demonstrates, the differences that make a difference between rural and urban Mexican spaces are in flux. She describes the body of research devoted to rural Mexico in the $20^{\text {th }}$ century as a matter of "cumulative dialectical encounter with the countryside" (1989: 187).

${ }^{14}$ Andrew S. Mathews, for example, has shown that these distinctions have significant implications for practices involved in knowledge projects (Mathews 2006).
} 
break into any field station and vandalize or steal components. For station maintenance and design, these issues were all tracked and all considered.

Keeping this seismic monitoring project online allows the Sistema Alerta Sísmica Mexicano to be ready to produce warnings at any time for people at risk, and abstract reflections on these conditions were not sufficient for that. As Gómez made clear in our conversation, going out meant encountering something "different" than Mexico City. While those experiences might be suggested by general reflections on challenges understood and made possible by the needs of people at risk in a handful of cities, their sensory practices in the field allowed engineers and technicians to know that political territory in more particularistic ways too.

\section{A world we don't know}

Teams of two or three engineers and technicians regularly traveled to the field for a week or more, visiting station after station as directed from CIRES's Mexico City center of coordination. These teams were generally comprised of young men. Born, raised, trained, and still living in the Mexico City metropolitan area as most were, the environmental and social conditions distinctive to various sites in the field were far from ordinary for them. The engineers had recent professional degrees in engineering, and the technicians were working toward such a certification or had significant technical experience. ${ }^{16}$ For their work (Figure 5), they left their Mexico City lives behind to visit each field station in the Sistema Alerta Sísmica Mexicano three or four times each year. Field teams went out prepared for a variety of different circumstances that they might encounter, but also for surprising irregularities, idiosyncratic and emergent local conditions. José Pérez, an engineer who regularly led teams into these places, described going to the field as an encounter with "a world that we don't know." He was, to put it another way, prepared to be confronted with difference and produce topological knowledge.

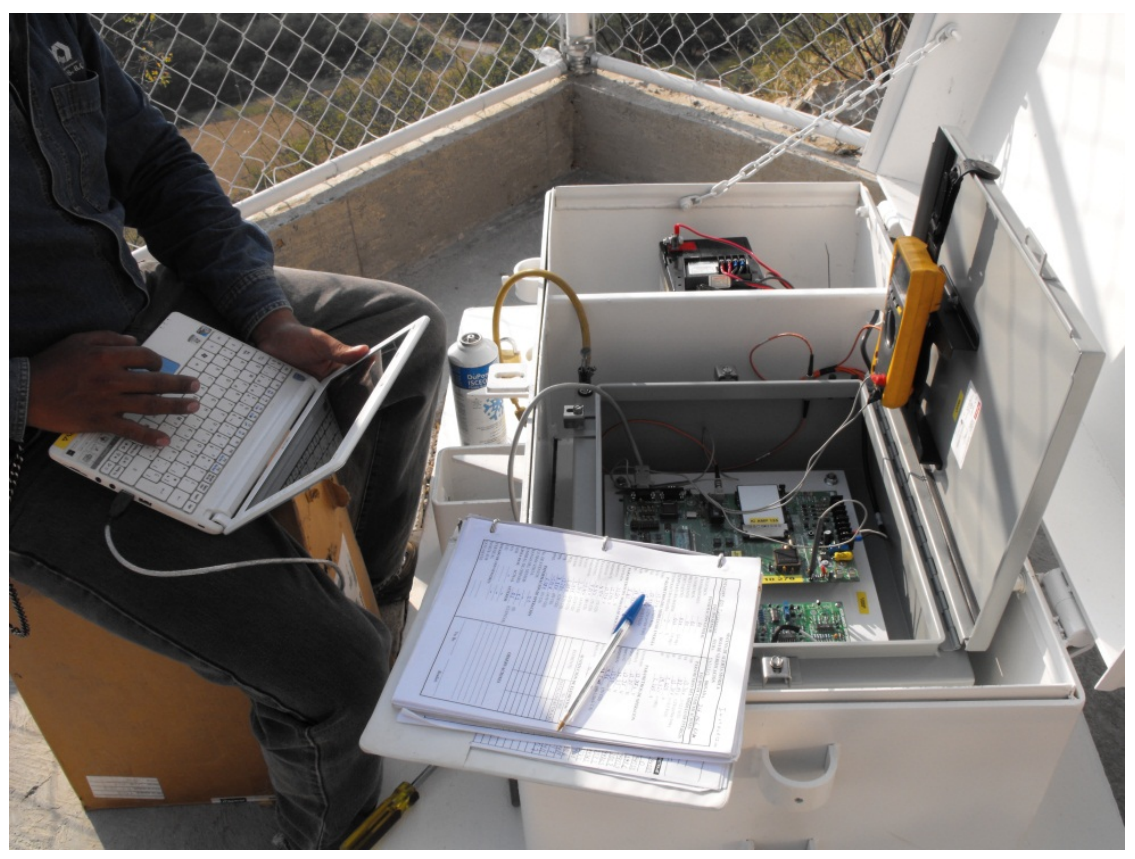

Figure 5: Work on a field station. Source: CIRES, 2014.

\footnotetext{
${ }^{16}$ Again, this is demonstrated by observations, interviews, and an anonymous survey I conducted in 2014.
} 
Seismic monitoring required extensive data collection. Field teams documented their work and the conditions around the stations carefully, and they maintained contact with CIRES headquarters while in the field. Later, on their return to Mexico City, they could illustrate their reports with photos of work undertaken, the condition of a station component, or a road made impassible by flood. Doing the topological work of building knowledge at CIRES headquarters about these specific field stations and what happened there was an important part of their fieldwork. Documenting every step of their work gave field teams material to discuss at CIRES headquarters. Through photographs, reports, and stories about siting and maintaining stations, they let those of us who stayed in Mexico City engage with the particular kinds of physical and social qualities of the varied territories that they encountered. These reports document minute variations in nearly identical stations: their poured concrete bases, chain link fences, radio towers, solar panels, metal boxes of computer equipment, and accelerometers underground. These contribute to knowledge that is not about contiguous territory, but attends to difference, change, and the relations established between these stations and Mexico City.

Some of what they can sense and document of this still- unknown world is systematically enrolled in the seismic monitoring project whether the issue in question was meteorological or anthropogenic (see, for example, Jimenez et al. 1993). The documented presence of an ant infestation or the effects of a storm, corrosion, or theft could be considered in ongoing station redesign efforts undertaken by the CIRES Design Department in their laboratory in Mexico City. ${ }^{17}$ However, field teams also encountered conditions that were more difficult to sense and document, and which had to be enrolled in knowledge production differently. These are the basis of topological knowledge about complex, shifting conditions that can seep into the boots of engineers and technicians, steam them in their truck cabs, slide their wheels on the road, sting them, and threaten them in other ways.

In 2014, while I visited Mexico City, "the field" held particularly significant dangers for stations and for these engineers and technicians who ventured out from CIRES headquarters to visit them. That September, 43 student teachers had vanished while traveling through Guerrero state, bringing renewed and national and international attention to the central role that organized crime had taken on in many Mexican communities. ${ }^{18}$ While the Ayotzinapa 43 were especially well-covered by the news media, the Mexican government counted more than 20,000 murders during the year that I worked in CIRES headquarters-lower than the level the national rate had reached in 2011, but still more than double that reported in 2007. ${ }^{19}$ Guerrero and Michoacán are among the states made most dangerous by organized crime (Viridiana Rios 2013), and together they hold nearly half of the seismic monitoring system's field stations within their borders. These places were truly dangerous for field teams, but patterns in these conditions were inconsistent. CIRES directors consider rumor as evidence when they decide whether or not to send engineers and technicians to visit certain field stations just as they consider more concrete evidence of seasonal storms.

Their work to maintain the earthquake monitoring system brings engineers and technicians to encounter these conditions, too. Their topological knowledge about violence is produced through in less direct sensory practices than those which render knowledge about the conditions of field stations. Rather than clear evidence of corrosion that can be photographed, or damaged components that can be taken to Mexico City for further evaluation, field teams might have the impression that soldiers at army checkpoints who had questioned and threatened them were not army at all but a militia in disguise (Figure 6). These spaces might be considered, in Raymond Craib's terms, "fugitive landscapes" (2004: 57)—not merely unknown, but actively resistant to official and state-sanctioned sensory practices and knowledge projects like seismic monitoring. In these

\footnotetext{
${ }^{17}$ Station redesigns often address multiple issues at once. Station components last longer if they use less power, and smaller panels are less appealing to the thieves who can damage stations just as thoroughly as lightning strikes, and CIRES engineers explained to me that design choices regarding the energy requirements of field stations were influenced by both human and nonhuman forces and agents.

${ }^{18}$ See, for example, Francisco Goldman's excellent reporting for the New Yorker (2014).

${ }^{19}$ As reported in INEGI (2018). Not all can be associated with organized crime, certainly, but the incredible size of the difference between murder rates in 2014 and 2007 is significant. Further, these numbers do not include those whose remains have not been found, who may be officially considered "missing."
} 
contexts, the inconsistent reach of Mexican state law frames the kinds of sensory practices field teams can use, and is reflected in the kinds of topological knowledge that they produce.

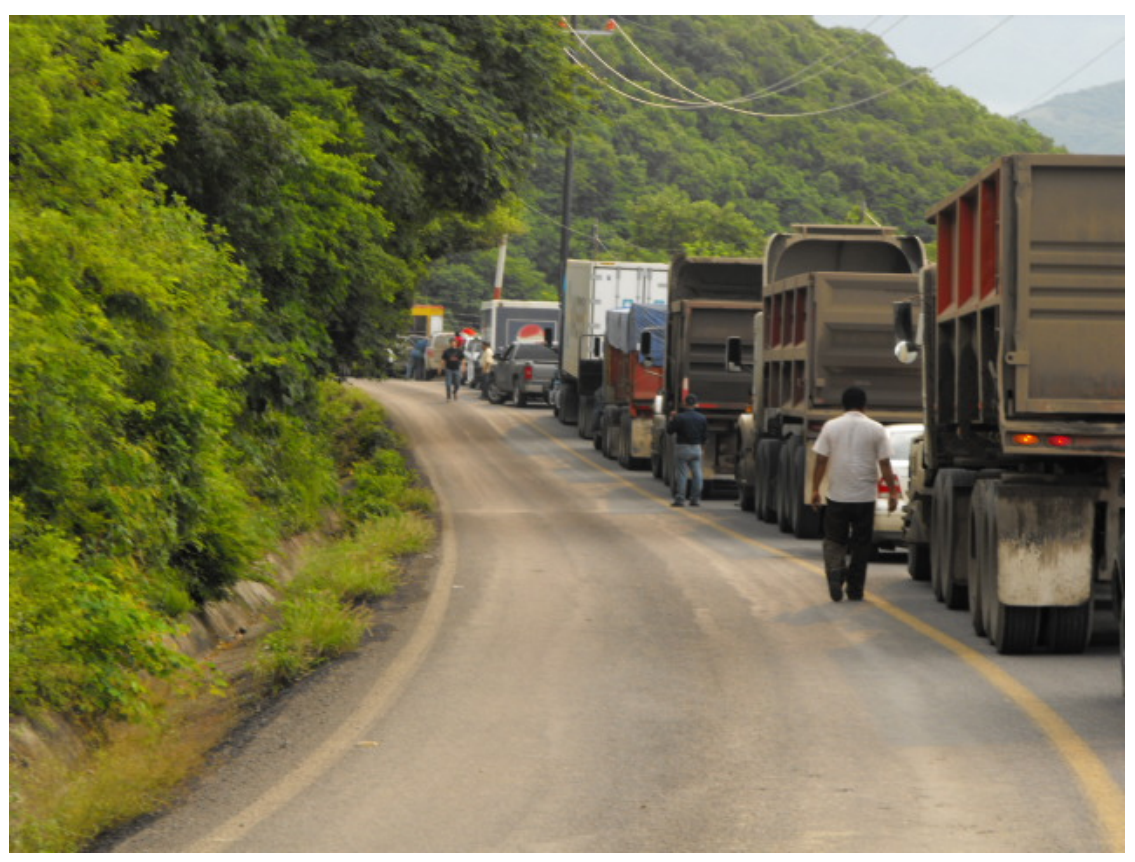

Figure 6: A blocked road. Source: CIRES, 2014.

"This is how we indirectly realize how things are", Pérez explained, emphasizing this difference between the direct sensory encounters with earthquakes or station conditions that facilitated the production of knowledge and the indirect encounters through which field teams learned about lived reality of violence in many parts of rural Mexico. He remembered one town in Michoacán where he met a man who told him about local people involved in what he called "drugs, the mafia, and all that." These people could force him to sell them his produce for an absurdly low rate. "They paid him 1.50 pesos per kilo of papaya," (c.8 cents) Pérez told me. "Can you imagine? Here in Mexico City a kilo of papaya costs 25 or 30 pesos." (US\$1.30-1.55). He called it an insult, a grosería. The farmer had no options, he explained, because he lived so far into territory controlled by organized criminals. "It's a little frustrating because you notice all the richness that there is in the nation, exploited by a few people...This was one of the things that gave us a real panorama of what happens outside of the city."

The kind of sensory practices and knowledge that field teams develop about the social world "outside the city" is not the same as the knowledge about seismicity that they make possible, or even the knowledge about the conditions of station equipment that they can evaluate and document exhaustively. Pérez describes varying, emergent data as well as a general distinction between CIRES and the field. Knowledge configuration here reflects complex political arrangement of space. Knowledge about seismicity, social conditions, and particular stations takes topological and topographic form in light of sensory practices that are enabled, constrained, and shaped by Mexican territorial politics.

\section{Conclusion}

When they return from the field, CIRES engineers and technicians put their equipment away. They make reports and tell stories while bright rain jackets dry on their trucks' rearview mirrors, some evidence of their travels evaporating away while other kinds are circulated (Figure 7). They and their colleagues incorporate their detailed and less detailed reports into plans to tend to some repairs, to redesign equipment, to visit stations or 
leave them out of commission until local violence has subsided. They and their colleagues draw on their field trips to produce knowledge about Mexico. Although their work is explicitly about seismicity, it requires diverse sensory practices and the production of knowledge about issues including social conditions in rural Mexico. Further, as I have demonstrated, not only can seismic and more-than-seismic knowledge they produce can be configured spatially as topographic or topological.

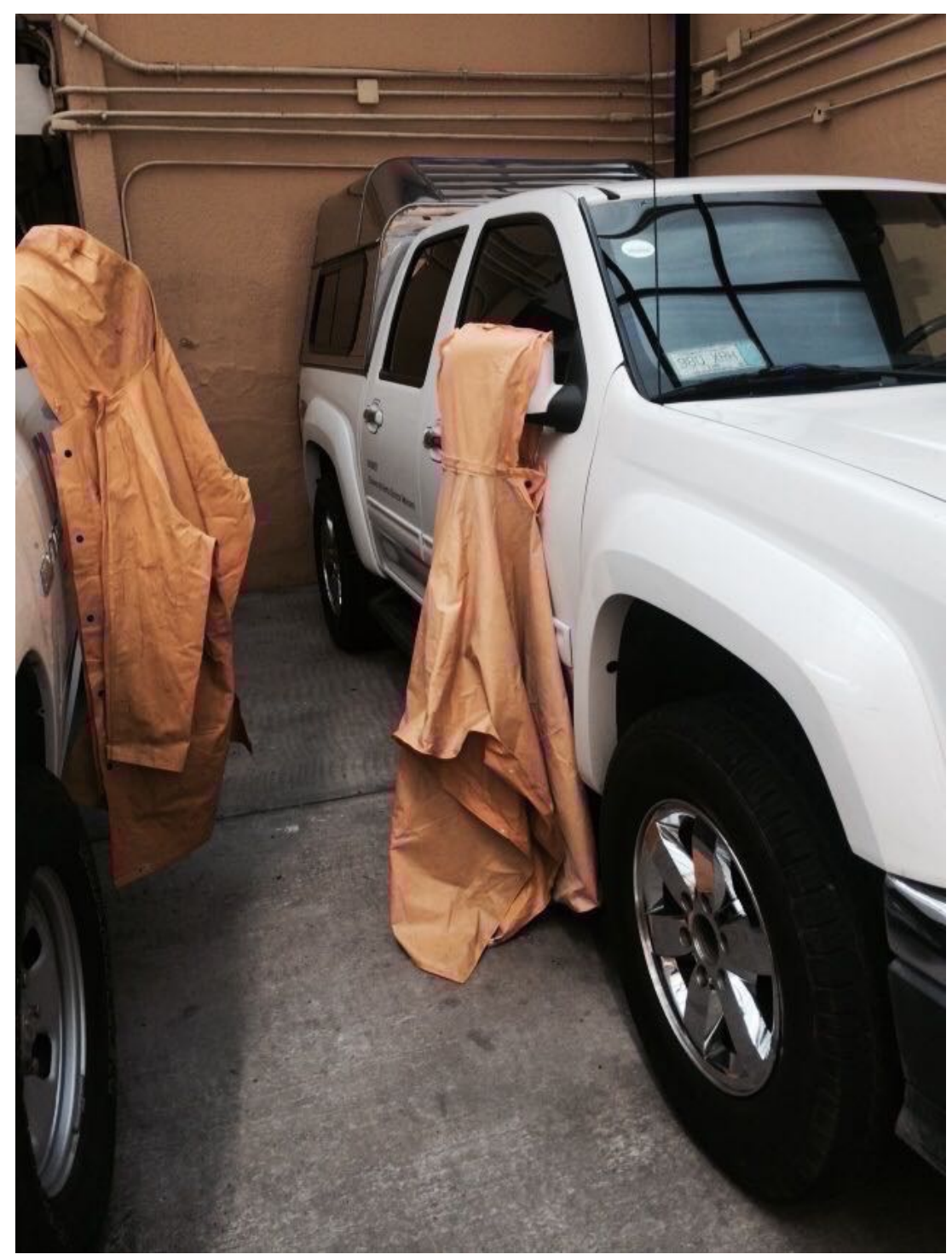

Figure 7: Raincoats on trucks. Source: Author 2014.

Like everyone else in CIRES headquarters, I kept an eye on the simple digital map of seismic Mexico and its glowing dots and sweeping lines and listened to stories of the field which dealt with the idiosyncratic, particular surprises that each of the 98 station sites held for field teams. I used the stories and documentation that the engineers and technicians produced to understand how Sistema Alerta Sísmica Mexicano's seismic monitoring project could entail many different sensory practices and knowledge projects, and how territorial politics might frame and emerge out of them. 
Off the coast, the Cocos and North American tectonic plates continue to move against each other. When they slip and release massive waves of energy, the Sistema Alerta Sísmica Mexicano will frame a very simple message about an earthquake of significant size on its way at the CIRES offices and for users. ${ }^{20}$ As engineers and technicians maintain this system, they experience what arrangements of Mexican power mean in the difficult environmental and social conditions of what they call "the field." Their practices make knowledge necessary to seismic monitoring, but their new understandings of Mexican territory might have other kinds of impacts in their lives. The young men I interviewed suggested that this work changes the way they understand Mexico. These effects, however, are less documented then Mexican seismicity or the effects of storms on field stations. ${ }^{21}$

\section{References}

Allen, J. 2011. Topological twists: power's shifting geographies. Dialogues in Human Geography 1(3): 283298.

Asfura-Heim, P. and R.H. Espach. 2013. The Rise of Mexico's self-defense forces vigilante justice south of the border. Foreign Affairs. https://www.foreignaffairs.com/articles/mexico/2013-06-11/rise-mexico-s-selfdefense-forces [accessed May 17 2018]

Bartra, R. 1993. Agrarian structure and political power in Mexico. Baltimore: Johns Hopkins University Press.

Bazant, M. 2014. Historia de la educacion durante el Porfiriato. Mexico City: El Colegio de Mexico.

Belcher, O., L. Martin, A. Secor, S. Simon and T. Wilson. 2008. Everywhere and nowhere: the exception and the topological challenge to geography. Antipode 40(4): 499-503.

Bier, J, 2017. Mapping Israel, mapping Palestine: how occupied landscapes shape scientific knowledge. Cambridge: MIT Press.

Biersack, A. 2006. Reimagining political ecology: culture/power/history/nature. In A. Biersack and J.B. Greenberg (eds.) Reimagining political ecology. Durham: Duke University Press. Pp. 16-53.

Bonfil Batalla, G. 2004. México profundo: reclaiming a civilization. Austin: University of Texas Press.

Classen, C. 1997. Foundations for an anthropology of the senses. International Social Science Journal 49(153): 401-412.

Coleman, M. 2011. Topologies of practice. Dialogues in Human Geography 1(3): 308-311.

Collins, T. 2008. The political ecology of hazard vulnerability: marginalization, facilitation and the production of differential risk to urban wildfires in Arizona's White Mountains. Journal of Political Ecology 15(1): 21-43.

Connor, S. 2006. The menagerie of the senses. The Senses and Society 1(1): 9-26.

Craib, R.B. 2004. Cartographic Mexico: a history of state fixations and fugitive landscapes. Durham: Duke University Press.

Crampton, J.W. 2011. Cartographic calculations of territory. Progress in Human Geography 35(1): 92-103.

Csordas, T. 1993. Somatic modes of attention. Cultural Anthropology 8(2): 135-156.

Cuéllar, M. A., G. Ibarrola Álvarez, S. Maldonado C. and J.M. Espinosa Aranda. 2010. Sistema de alerta sísmica para la Ciudad de México. Revista Digital Universitaria 11(1): 1-10.

Dodge, M., R. Kitchin and C. Perkins (eds.) 2011. Rethinking maps: new frontiers in cartographic theory. London: Routledge.

\footnotetext{
${ }^{20}$ Indeed, this was possible on September 8, 2017, but sadly less so on September 19th when a quake emerged from a fault where CIRES had not positioned field stations.

${ }^{21}$ When mapping projects explicitly take on politics, it often happens through the creation of what Young and Gilmore call a "politically potent map." They make the case that this approach assumes a "rational and deliberative" system in which claims simply need to be made in the right ways (2013: 814). Just as a map is not necessarily an accurate reflection of the world, nor do its political effects need to be conceptualized as direct (see also Gerlach 2015).
} 
Edwards, P.N. 2010 A vast machine: computer models, climate data, and the politics of global warming. Cambridge: MIT Press.

Elden, S. 2011. What's shifting? Dialogues in Human Geography 1(3): 304-307.

Elden, S. 2013. Secure the volume: vertical geopolitics and the depth of power. Political Geography 34: 3551.

Eren, A. 2017. The political ecology of uncertainty: the production of truth by juridical practices in hydropower development. Journal of Political Ecology 24(21): 386-405.

Escobar, A. 1999. After nature: steps to an anti-essentialist political ecology. Current Anthropology 40(1): 130.

Espinosa-Aranda, J.M., A. Cuélllar, F.H. Rodríguez, B. Frontana, G. Ibarrola, R. Islas and A. García. 2011. The seismic alert system of Mexico (SASMEX): progress and its current applications. Soil Dynamics and Earthquake Engineering 31(2): 154-162.

Espinosa-Aranda, J.M, A. Cuellar, A. Garcia, G. Ibarrola, R. Islas, S. Maldonado and F. Rodriguez. 2009. Evolution of the Mexican seismic alert system (SASMEX). Seismological Research Letters 80(5): 694.

Forsyth, T.J. 2003. Critical political ecology: the politics of environmental science. London: Routledge.

Foucault, M. 2009. Security, territory, population: lectures at the Collège de France 1977-1978. London: Macmillan.

Gabrys, J, 2016. Program earth: environmental sensing technology and the making of a computational planet. Minneapolis: University of Minnesota Press.

Gerlach, J. 2015. Editing worlds: participatory mapping and a minor geopolitics. Transactions of the Institute of British Geographers 40(2): 273-86.

Geurts, K. 2003. Culture and the senses: bodily ways of knowing in an African community. Berkeley: University of California Press.

Geurts, K.L. 2002. On rocks, walks, and talks in West Africa: cultural categories and an anthropology of the senses. Ethos 30(3): 178-198.

Goldman M. and M. Turner. 2011 Introduction. In M. Goldman, P. Nadasdy, and M. Turner (eds.) Knowing nature: conversations at the intersection of political ecology and science studies. Chicago: University of Chicago Press: 1-23.

Goldman, F. 2014. Crisis in Mexico: the disappearance of the forty-three. New Yorker, October. http://www.newyorker.com/news/news-desk/crisis-mexico-disappearance-forty-three [accessed May 17 2018]

Grayson, G.W. 2010. Mexico: narco-violence and a failed state? New Brunswick: Transaction Publishers.

Gupta, A. and J. Ferguson. 1997. Discipline and practice: "the field" as site, method, and location in anthropology. In A. Gupta and J. Ferguson (eds.) Anthropological locations: boundaries and bounds of a field science. Berkeley: University of California Press. Pp. 1-46.

Guardino, P.F. 2002. Peasants, politics, and the formation of Mexico's national state: Guerrero, 1800-1857. Palo Alto: Stanford University Press.

Harley, J.B. 1989. Deconstructing the map. Cartographica: The International Journal for Geographic Information and Geovisualization 26(2): 1-20.

Harvey, P. 2012. The topological quality of infrastructural relation: an ethnographic approach. Theory, Culture and Society 29(4/5):76-92.

Hayward, E. 2010. Fingeryeyes: impressions of cup corals. Cultural Anthropology 25(4):577-599.

Henare, A., M. Holbraad and S. Wastell. 2007. Thinking through things: theorising artefacts ethnographically. New York: Routledge.

Hewitt de Alcantara, C. 1984. Anthropological perspectives on rural Mexico. London: Routledge

Howes, D. 2003. Sensual relation: engaging the senses in culture and social theory. Ann Arbor: University of Michigan Press. 
Instituto Nacional de Estadística y Geografía (INEGI) 2018. Mortalidad: conjunto de datos: defunciones por homicidios. http://www.inegi.org.mx/lib/olap/consulta/general_ver4/MDXQueryDatos.asp?proy= [accessed May 17, 2018]

Jiménez, A., J.M. Espinosa Aranda, F. Alcántara and I. Garcia. 1993. Analisis de confiabilidad del sistema de alerta. In $X$ Congreso Nacional de Ingeniería Sísmica. October 8th-11th Puerto Vallarta, Jalisco: Sociedad Mexicana de Ingeniería Sísmica. Pp. 629-634.

Joseph, G.M. and D. Nugent (eds.) 1994. Everyday forms of state formation: revolution and the negotiation of rule in modern Mexico. Durham: Duke University Press.

Keating, E. and R.N. Hadder. 2010. Sensory impairment. Annual Review of Anthropology 39(1): 115-129.

Kitchin, R. and M. Dodge. 2007. Rethinking maps. Progress in Human Geography 31(3): 331-344.

Lantz, A. 2016. The performativity of violence: abducting agency in Mexico's drug war. Journal of Latin American Cultural Studies 25(2): 253-69.

Lave, R. 2012. Neoliberalism and the production of environmental knowledge. Environment and Society 3(1): 19-38.

Lefebvre, H. 1991. The production of space. Oxford: Blackwell.

Lomnitz-Adler, C. 1991. Concepts for the study of regional culture. American Ethnologist 18(2): 195-214

Lury, C., L. Parisi and T. Terranova. 2012. Introduction: the becoming topological of culture. Theory, Culture and Society 29(4/5): 3-35.

Marres, N. 2012. On some uses and abuses of topology in the social analysis of technology (or the problem with smart meters). Theory, Culture and Society 29(4/5): 288-310.

Martin, L. and A.J. Secor. 2014. Towards a post-mathematical topology. Progress in Human Geography 38(3): 420-438.

Mathews, A.S. 2006. Building the town in the country: official understandings of fire, logging and biodiversity in Oaxaca, Mexico, 1926-2004. Social Anthropology 14(3): 335-59.

Mathews, A.S. 2008. State making, knowledge, and ignorance: translation and concealment in Mexican forestry institutions. American Anthropologist 110(4): 484-94.

Mezzadra, S. and B. Neilson. 2012. Between inclusion and exclusion: on the topology of global space and borders. Theory, Culture and Society 29(4-5): 58-75.

Nadim, T. 2016. Blind regards: troubling data and their sentinels. Big Data and Society 3(2): 1-6.

Neyland, D. 2006. The accomplishment of spatial adequacy: analysing CCTV accounts of British town centres. Environment and Planning D: Society and Space 24(4): 599-613.

Oliver-Smith, A. 1996. Anthropological research on hazards and disasters. Annual Review of Anthropology 25.

Paasi, A. 2011. Geography, space and the re-emergence of topological thinking. Dialogues in Human Geography 1(3): 299-303.

Peluso, N.L. and M.J. Watts (eds.). 2001. Violent environments. Ithaca: Cornell University Press.

Rahder, M. 2014. Caring for xate, caring for xateros: NGO monitoring, livelihoods, and plant-human relations in Uaxactún, Guatemala. Journal of Political Ecology 21(1): 372-388.

Ramos Lara, M, and R. Rodríguez Benítez (eds.) 2007. Formación de ingenieros en el México del siglo XIX. Mexico City: Universidad Nacional Autónoma de México Press.

Reddy E. 2016. The production of earthquake emergencies: technoscientific Earthquake Early Warning in a social and material world. Revista Iberoamericana de Comunicación 30: 17-44.

Rival, L. 2014. Encountering nature through fieldwork: expert knowledge, modes of reasoning, and local creativity. Journal of the Royal Anthropological Institute 20: 218-236.

Rocheleau, D.E. 2011. Rooted networks, webs of relation, and the power of situated science: bringing the models back down to Earth in Zambrana. In M. Goldman, P. Nadasdy and M. Turner (eds.) Knowing nature, transforming ecologies: a conversation between science and technology studies and political ecology. Chicago: University of Chicago Press. Pp. 209-226. 
Ruppert, E. 2012. The governmental topologies of database devices. Theory, Culture and Society 29(4/5):116136.

Secretaria de Educación Pública. 2016. Principales cifras del sistema educativo nacional 2015-2016. Mexico City: Dirección General de Planeación, Programación y Estadística Educativa.

Seremetakis, N.C. 1994. Perception and memory as material culture in modernity. Boulder: Westview.

Shields, R. 2012. Cultural topology: the seven bridges of Konigsburg, 1736. Theory, Culture and Society 29(45): 43-57.

Solomon, O. 2010. Sense and the senses: anthropology and the study of autism. Annual Review of Anthropology 39: 241-259.

Steinberg, P. and K. Peters. 2015. Wet ontologies, fluid spaces: giving depth to volume through oceanic thinking. Environment and Planning D: Society and Space 33: 247-264.

Strauss, J.A. and R.M. Allen. 2016. Benefits and costs of earthquake early warning. Seismological Research Letters 87(3): 765-772.

Suchman, L. 1997. Centers of coordination: a case and some themes. In L.B. Resnick, R. Säljö, C. Pontecorvo and B. Burge (eds.) Discourse, tools, and reasoning: essays on situated cognition. Berlin: SpringerVerlag. Pp. 41-62.

Tierney, K. J. 2007. From the margins to the mainstream? Disaster research at the crossroads. Annual Review of Sociology 33: 503-525.

Verplanke, J., M.K. Mccall, C. Uberhuaga, G. Rambaldi and M. Haklay. 2016. A shared perspective for PGIS and VGI. The Cartographic Journal 53(4): 308-317.

Young, J.C. and M.P. Gilmore. 2013. The spatial politics of affect and emotion in participatory GIS. Annals of the Association of American Geographers 103(4): 808-823.

Zagato, A. 2018. State and warfare in Mexico. Social Analysis 62(1): 55-75. 